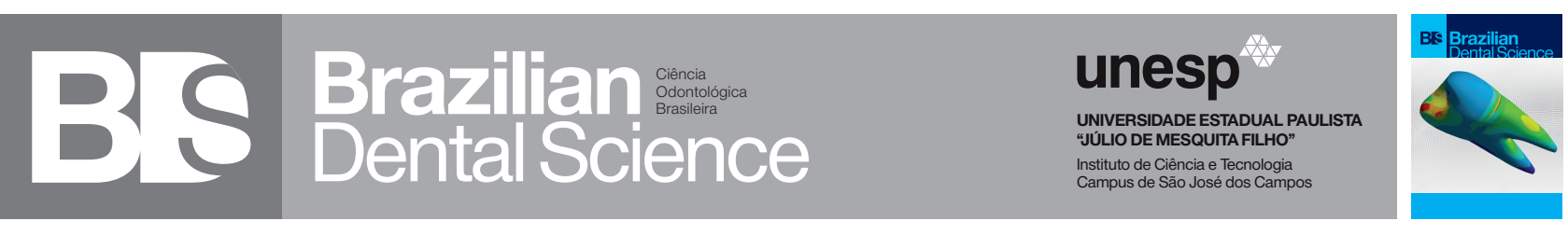

\title{
Surface roughness and volumetric contraction of a Y-TZP ceramic sintered by microwave energy and by resistive heating
}

Rugosidade da superfície e contração volumétrica de uma cerâmica Y-TZP sinterizada por energia de microondas e por aquecimento resistivo

\author{
Nayara BARCHETTA ${ }^{1}$, Larissa NANNI ${ }^{2}$, Jean MIRANDA ${ }^{1}$, Dolores LAZAR $^{3}$, Valter ASSUI ${ }^{3}$, Guilherme SAAVEDRA ${ }^{1}$ \\ 1 - São Paulo State University (Unesp) - Institute of Science and Technology - São José dos Campos - Department of Dental Materials and \\ Prosthodontics - SP - Brazil. \\ 2 - São Paulo State University (Unesp) - Institute of Science and Technology - São José dos Campos - SP - Brazil. \\ 3 - Institute of Energy and Nuclear Research (IPEN) - São Paulo - SP - Brazil.
}

\begin{abstract}
Objectives: The aim of this study was to evaluate a Y-TZP ceramic sintered by a microwave protocol on volume shrinkage and surface roughness. Material and Methods: Twenty four $(\mathrm{N}=24)$ Y-TZP discs were fabricated by milling in CAD/ CAM for size standardization. The mean final dimensions of the specimens were $15 \mathrm{~mm} \mathrm{X} 1.6$ $\mathrm{mm}$. Samples were divided into 2 groups $(n=12)$ : conventional resistive heating sintering protocol (C - Control) and microwave sintering protocol (MO - experimental). For the characterization of the specimens, surface roughness ( $\mathrm{Ra}$ and $\mathrm{Rz}$ parameters) was evaluated with a roughness tester, and volume shrinkage was measured with a hand micrometer. Data were statistically evaluated by Student's t and Mann-Whitney U tests $(\alpha=0.05)$. Results: The roughness results were: $0.25 \mu \mathrm{m} \pm$ $0.02(\mathrm{Ra})$ and $2.68 \mu \mathrm{m} \pm 0.666(\mathrm{Rz})$ for the $\mathrm{MO}$ samples; $0.26 \mu \mathrm{m} \pm 0.04(\mathrm{Ra})$ and $2.73 \mu \mathrm{m} \pm$ 0.461 (Rz) for the C group (Ra: $\mathrm{p}=0.19$; Rz: $\mathrm{p}$ $=0.81)$. The shrinkage results was: $\mathrm{MO}(21.02 \%$ $\pm 2.70)$ and $C(20.10 \% \pm 0.52)(p=0.274)$. Conclusion: The conventional and microwave sintering methods were similar regarding surface roughness and volume shrinkage of Y-TZP dental ceramic.
\end{abstract}

\section{KEYWORDS}

Bioceramics; Microwave sintering; Roughness surface; Zirconia.

\section{RESUMO}

Objetivo: avaliar uma cerâmica de zircônia estabilizada com óxido de ítrio (Y-TZP) sinterizada por um protocolo em micro-ondas quanto à contração volumétrica e a rugosidade superficial. Material e Métodos: Vinte e quatro discos $(\mathrm{n}=24)$ de Y-TZP foram fresados em CAD / CAM para padronização do tamanho. A dimensões finais médias dos corpos de prova foram de $15 \mathrm{~mm} \mathrm{X} \mathrm{1,6} \mathrm{mm.} \mathrm{As} \mathrm{amostras}$ foram divididas em 2 grupos $(n=12)$ : protocolo de sinterização convencional por aquecimento resistivo (C - Controle) e protocolo de sinterização por microondas (MO - experimental). A caracterização das amostras foi realizada pela avaliação da rugosidade superficial, com um rugosímetro (parâmetros Ra e Rz) e da contração volumétrica, medida com um micrômetro manual. Os dados foram estatisticamente avaliados pelos testes de t-Studant e U-Mann-Whitney $(\alpha=0,05)$. Resultados: Os resultados de rugosidade foram: 0,25 $\mu \mathrm{m} \pm 0,02$ (Ra) e 2,68 $\mu \mathrm{m} \pm 0,666(\mathrm{Rz})$ para o $\mathrm{MO}$; e 0,26 $\mu \mathrm{m}$ $\pm 0,04(\mathrm{Ra})$ e $2,73 \mu \mathrm{m} \pm 0,461(\mathrm{Rz})$ para o grupo $\mathrm{C}$ (Ra: $p=0,19 ; R z: p=0,81)$. A contração volumétrica foi de: $\mathrm{MO}(21,02 \% \pm 2,70)$ e C $(20,10 \% \pm 0,52)$ $(\mathrm{p}=0,274)$. Conclusão: os métodos de sinterização convencionais e de microondas são semelhantes, no que diz respeito à rugosidade superficial e retração de volume da cerâmica dental Y-TZP.

\section{PALAVRAS-CHAVE}

Cerâmicas; Rugosidade superficial; Sinterização por micro-ondas; Zirconia. 


\section{INTRODUCTION}

$Y^{\prime}$

ttria stabilized tetragonal zirconia polycrystalline (Y-TZP), previously used in the medicine industry, has begun to occupy a place in dentistry with the development of the CAD-CAM technology [1]. This ceramic has good properties such as biocompatibility, aesthetics, high hardness, chemical inertia and favorable tribological characteristics [1-6]. Studying some of these properties and characteristics is fundamental for its clinical validation. Surface roughness (SR), for example, is directly related to the quality of the micromechanical retention between the zirconia, the cement and the veneering porcelain [7]. In addition, the surface texture may also influence the translucency, opalescence and mimicry of the natural dental element [8-9].

Due to sintering, zirconia undergoes a dimensional alteration denominated volumetric contraction [10]. This is also an important index to be evaluated, since zirconia restorations are made by milling a CAD/CAM ceramic, trying to minimize the errors and the mismatch of the ceramic on the tooth [1].

Ceramics with good mechanical properties are generally highly dense and composed of submicron grains, which in turn depends on the elimination of porosities and grain growth control in the sintering process [11]. This can occur in a conventional zirconia oven at a specific temperature over a long period of approximately 10 hours [12-13]. However, there is also the possibility of sintering in a microwave oven, which generates benefits to the process as well as reducing processing time [14]. This oven emits electromagnetic waves that can be transmitted, absorbed and/or reflected depending on the material, thus allowing the heating in a fast and uniform way, which reduces thermal stresses and avoids the induction of cracks and damages to the material [15].
Regarding this technique, there are studies that recommend different times and temperatures [10-16]. However, the effect of these variations on the mechanical properties and microstructure of zirconia is not yet known. A protocol was developed by Barchetta [14] for sintering dental zirconia by microwave energy at a temperature of $1450^{\circ} \mathrm{C}$ in $15 \mathrm{~min}$. It was proved that this protocol is compatible with the conventional, but presents a time advantage [14].

Since it is a new methodology to sinter the Y-TZP, there is a shortage of comparative studies about the microstructural characteristics of the ceramic obtained by these two methods. Therefore, surface roughness and volumetric contraction of a Y-TZP ceramic sintered by microwave energy and by conventional resistive heating were evaluated in this research. The null hypothesis is that there would be no difference between the surface roughness and the volumetric contraction found by the conventional and microwave sintering technique.

\section{MATHERIAL AND METHODS}

\section{Specimens preparation:}

Pre-sintered blocks of polycrystalline tetragonal zirconia stabilized by yttrium oxide (VIPI Block Zirconn, VIPI Pirassununga, SP, Brazil) were milled in a four axis CAD/CAM machine (Mini K4, VIPI, Pirassununga, SP, Brazil) to obtain twenty-four disk-shaped samples, which should have dimensions of $15 \mathrm{~mm}$ thickness and $1.6 \mathrm{~mm}$ in diameter after sintering in the oven (Figure 1).

The samples were randomly allocated into 2 groups $(n=12)$ : one in which the sintering was done in a conventional resistive oven for zirconia (C); and another in which the sintering was made in microwave oven customized for zirconia sintering (MO). 
The sintering in the $\mathrm{C}$ group was done in a Zyrcomat T oven (Vita, Zahnfabrick, Germany) at $1530^{\circ} \mathrm{C}$ for 2 hours; however, the cycle lasted ten hours with the heating and cooling time. On the other hand, microwave sintering (MO group) was performed in an oven with $1.4 \mathrm{KW}$ at 2.45 $\mathrm{GHz}$, customized for sintering the zirconia at a temperature of $1450^{\circ} \mathrm{C}$ for 15 minutes (INTI, Brazil). This cycle lasted one hour and forty-five minutes including heating and cooling time.

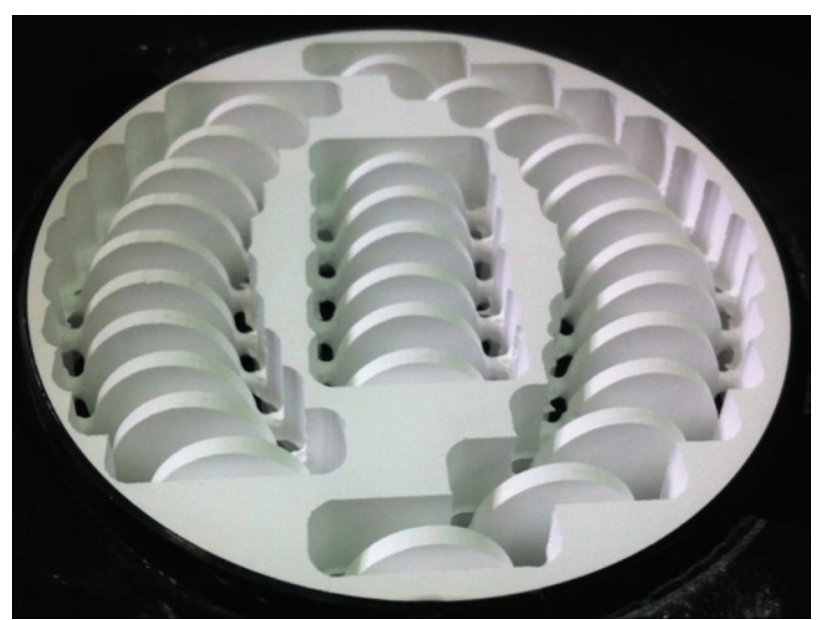

Figure 1 - Illustrative image of the pre-sintered Y-TZP discs milled with CAD-CAM technology

\section{Surface roughness analysis:}

The surface roughness quantitative analysis was performed using a micro-durometer (Mitutoyo SJ 400, Mitutoyo, Tokyo, Japan). Mean roughness (Ra) corresponds to the arithmetic mean of the absolute values of the spacing ordinates (peaks and valleys) in relation to the midline within the measurement path; and mean depth roughness (Rz) corresponds to the arithmetic mean of the absolute values of the ordinates of the points of greatest distance, above and below the midline.

The analysis was performed in three samples per group, with three measurements in one direction, and thee in another direction perpendicular to the first, and $1 \mathrm{~mm}$ was taken between each measurement. Thus, the end of the rugosimeter had a $3 \mathrm{~mm}$ path and a mean value was obtained for each sample from the six data measurements.

The Student's t-test $(\alpha=0.05)$ was performed for analysis of the Ra and Rz data after the descriptive statistics. The confidence interval considered was $95 \%$.

\section{Analysis of volumetric contraction:}

Measurement of the volumetric contraction was performed using a manual bench micrometer (Figure 2). Measurements were made for all 12 specimens of each group, with two diameter measurements in two different points perpendicular to each other, in addition to five thickness measures in different points parallel to each other.

The arithmetic mean of diameter and thickness of each sample was calculated before and after sintering. Then, the contraction percentage values of each sample were calculated from the differences of the means before and after sintering of the zirconia discs. Statistical analysis was performed by Student's t and Mann-Whitney $\mathrm{U}$ tests, both using a significance level of $5 \%$ at 95\% confidence interval.

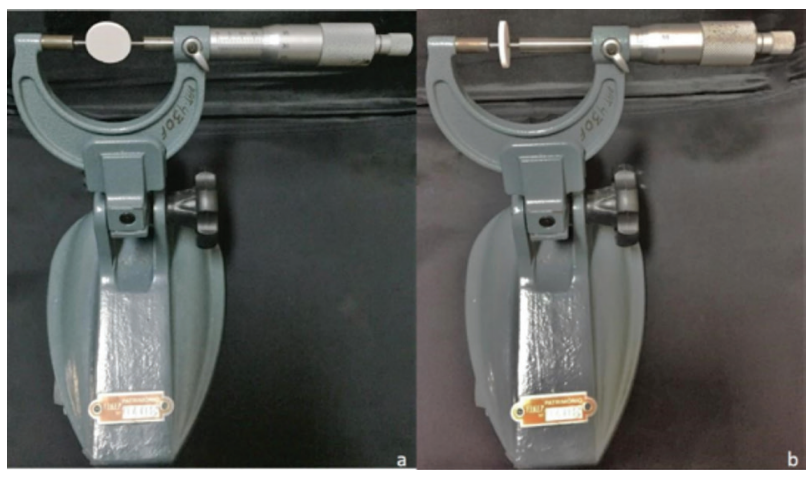

Figure 2 - Example of the (a) diameter measurement and (b) thickness of the zirconia disk, which were performed before and after sintering the ceramic 


\section{RESULTS}

\section{Surface Roughness:}

The means of Ra and $\mathrm{Rz}$ for group $\mathrm{C}$ were $0.26 \pm 0.04 \mu \mathrm{m}$ and $2.73 \pm 0.46 \mu \mathrm{m}$, respectively. For the MO group they were $0.25 \pm 0.02 \mu \mathrm{m}$ and $2.68 \pm 0.67 \mu \mathrm{m}$. They did not differ statistically between them (Ra: $\mathrm{p}=0.19$; Rz: $\mathrm{p}=0.81$ ) (Figures 3 and 4).

\section{Volumetric Contraction:}

For both statistical tests applied, the means of the MO group (21.02 $\pm 2.70 \mathrm{~mm} 2)$ and the C group $(20.10 \pm 0.52 \mathrm{~mm} 2)$ did not differ statistically $(\mathrm{p}=0.274)$ (Figure 5$)$.

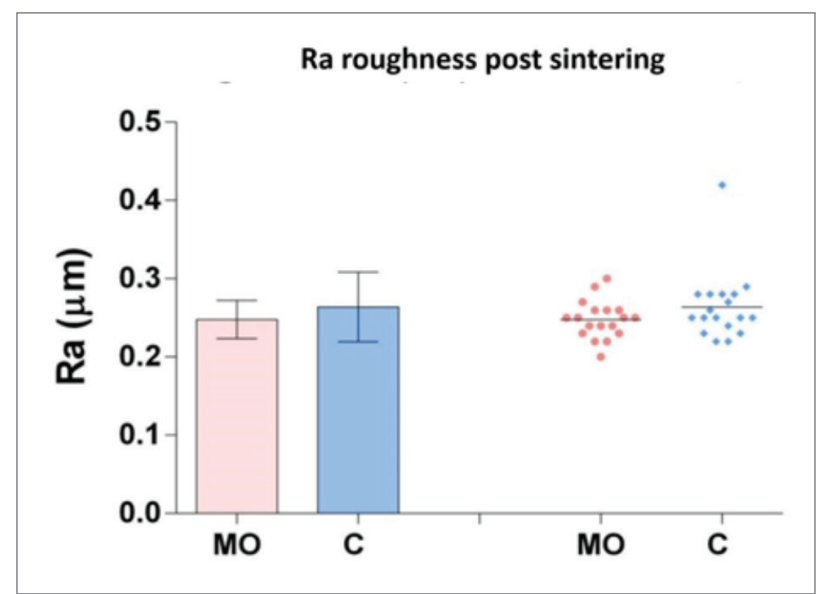

Figure $\mathbf{3}$ - Ra roughness post sintering. Column chart (mean \pm standard deviation). According to two methods of sintering: microwave $(\mathrm{MO})$ and conventional oven $(\mathrm{C})$

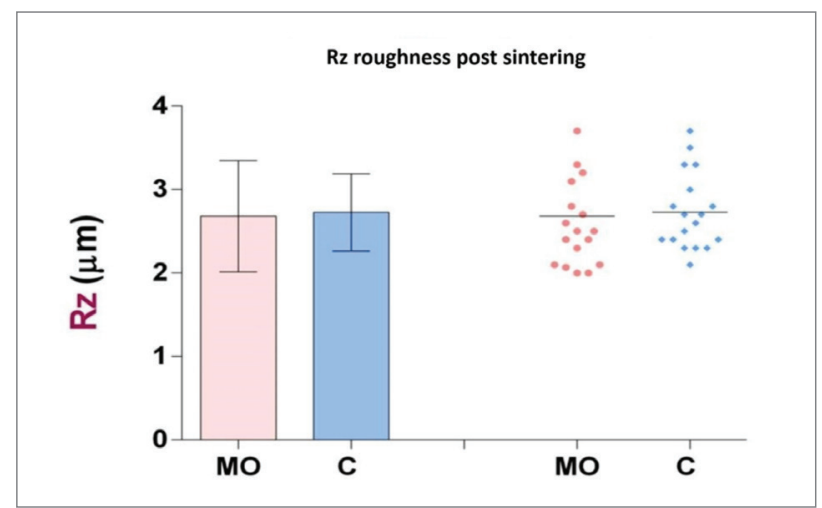

Figure 4 - Rz Roughness, post sintering. Column chart (mean \pm standard deviation). According to two methods of sintering: microwave $(\mathrm{MO})$ and conventional oven (C).

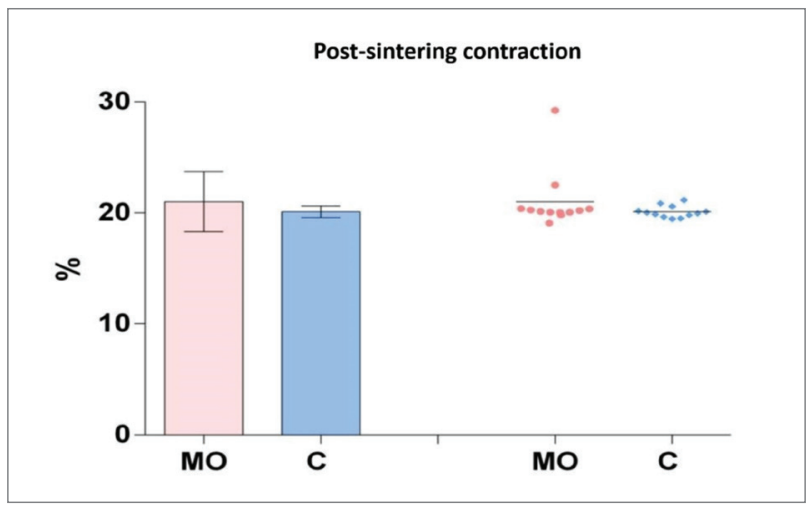

Figure 5 - Post-sintering contraction. Column chart (mean \pm standard deviation). According to two methods of sintering: microwave $(\mathrm{MO})$ and conventional oven (C)

\section{DISCUSSION}

Some studies have reported a quick and practical alternative for sintering Y-TZP ceramic by using microwave energy $[8,12-15,17,18]$. This research was conducted in order to evaluate the influence of this type of sintering oven on the surface roughness and the volumetric contraction of the zirconia.

The material properties evaluated in this study did not present a statistically significant difference between zirconia sintering using the conventional and the microwave oven, leading to the acceptance of the null hypothesis and corroborating previous studies that also evaluated these two techniques $[8,12,15-18]$.

The volume contraction value obtained for the MO group was approximately $21.02 \%$, while for the C group it was approximately $20.10 \%$, both being equivalent and not statistically different. These results are similar to the study by Almazdi et al. [12]. They evaluated volumetric contraction when applying the same techniques and observed that there was no difference between the groups, just as in the present study, and the mean contraction was around $24.6 \%$. In comparison with the present research, this small variation can be justified by the different commercial brand of zirconia, which also implies different compositions of this material. 
In comparing the volumetric contraction of the samples also obtained from these two sintering methods, Marinel and Savary [19] also found similar results to those previously reported, however they evaluated copper oxide.

In the case of surface roughness analysis, the results (Ra: $\mathrm{p}=0.19$; Rz: $\mathrm{p}=0.81$ ) present a favorable factor, because if an increase in roughness was observed by microwave sintering, aesthetic damage to the zirconia monolithic crowns would occur. This could favor bacteria colonization and the formation of a dental biofilm, which could lead to the appearance of caries and/ or periodontal disease, and consequently cause failure of the dental rehabilitation. Roughness can also influence the micromechanical retention between zirconia and cement, and between zirconia and veneering ceramics in the case of bilayers [20-23].

Comparing these two sintering techniques, a factor that can also be considered is the electric energy consumption. The power of a microwave oven is 1500W; however, a conventional resistive oven is $5000 \mathrm{~W}$. Considering the time of the sintering cycles with the use of each of the equipment, we have energy consumption of 22550 KWH for conventional oven, and $2175 \mathrm{KWH}$ in the case of the microwave oven, representing 10 times lower consumption to the microwave process. With less time and lower consumption spent with electric power, similar statistical results were obtained, not causing any damage to the ceramics according to the evaluated criteria. Based on the results presented in this study, the microwave sintering technique can be considered promising. However, sintering studies of Y-TZP by microwave energy in which other material properties of this ceramic should be performed and evaluated for better and safer indication of this technique.

\section{CONCLUSIONS}

Within the limitations of this study, it can be concluded that the methods of conventional and microwave sintering were statistically compared to volumetric contraction and surface roughness analysis.

\section{REFERENCES}

1. Cassoni A, Miranda PV, Rodrigues JA, Heluy SCL, Blay A, Shibli JA. Thermal effects on zirconia substrate after Er,Cr:YSGG irradiation. Rev Odontol UNESP. 2013 Nov-Dec;42(6):439-43.

2. Saavedra G, Ariki EK, Federico CD, Galhano G, Zamboni S, Baldissara P, et al. Effect of acid neutralization and mechanical cycling on the microtensile bond strength of glass-ceramic inlays. Oper Dent. 2009 Mar-Apr;34(2):211-6. doi: 10.2341/08-68.

3. Saavedra GSFA, Pedrique B, Cavalheiro RF, Borges AL, Paes-Junior TJ. Effect of thermal treatment on the bending strength of glass ceramic/resin cement. Braz Dent Sci. 2012 Oct-Dez;15(4):10-3.

4. Oh GJ, Park SW, Yun KD, Lim HP, Son HJ, Koh JT, et al. Effect of transition metal dopants on mechanical properties and biocompatibility of zirconia ceramics. J Nanosci Nanotechnol. 2013 Jun;13(6):4252-5.

5. Della Bona A. Characterizing ceramics and the interfacial adhesion to resin: I - the relationship of microstructure, composition, properties and fractography. J Appl Oral Sci. 2005 Mar;13(1):1-9.

6. Vagkopoulou T, Koutayas SO, Koidis P, Strub JR. Zirconia in dentistry: Part I. Discovering the nature of an upcoming bioceramic. Eur J Esthet Dent. 2009 Summer;4(2):130-51.

7. Aboushelib MN, Kleverlaan CJ, Feilzer AJ. Effect of zirconia type on its bond strength with different veneer ceramics. J Prosthodont. 2008 Jul;17(5):401-8. doi: 10.1111/j.1532-849X.2008.00306.x.

8. Kim MJ, Ahn JS, Kim JH, Kim HY, Kim WC. Effects of the sintering conditions of dental zirconia ceramics on the grain size and translucency. J Adv Prosthodont. 2013 May;5(2):161-6. doi: 10.4047/ jap.2013.5.2.161.

9. Hanning M. Transmission electron microscopic of early plaque formation on dental materials in vivo. Eur J Oral Sci. 1999 Feb;107(1):55-64.

10. Curran DJ, Fleming TJ, Towler MR, Hampshire S. Mechanical properties of hydroxyapatite-zirconia compacts sintered by two different sintering methods. J Mater Sci Mater Med. 2010 Apr;21(4):1109-20. doi: 10.1007/s10856-009-3974-z.

11. Trunec M. Effect of grain size on mechanical properties of 3Y-TZP ceramics. Ceram-Silikáty. 2008;52(3):165-71.

12. Almazdi AA, Khajah HM, Monaco EA Jr, Kim H. Applying microwave technology to sintering dental zirconia. J Prosthet Dent. 2012 Nov;108(5):304-9. doi: 10.1016/S0022-3913(12)60181-4. 
13. Menezes RR, Souto PM, Kiminami RHGA. Sinterizacão de cerâmicas em micro-ondas. Parte l: aspectos fundamentais. Cerâmica. 2007 Jan-Mar;53(325):1-10.

14. Barchetta NF, Luz JN, Arata A, Lazar DRR, Ussui, V, Saavedra GSFA. Método de sinterização de zircônia tetragonal policristalina estabilizada por ítria utilizando energia de micro-ondas. $\mathrm{Bra}$. $\mathrm{Br} 10$ 2016027954 2. 2016. [Patent]

15. Marinis A, Aquilino SA, Lund PS, Gratton DG, Stanford CM, DiazArnold AM, et al. Fracture toughness of yttria-stabilized zirconia sintered in conventional and microwave ovens. J Prosthet Dent. 2013 Mar;109(3):165-71. doi: 10.1016/S0022-3913(13)60037-2.

16. Menezes RR, Souto PM, Kiminami RHGA. Sinterização de cerâmicas em micro-ondas. Parte III: Sinterização de zircônia, mulita e alumina. Cerâmica. 2007;53:218-26.

17. Gelfuso MV, Capistrano D, Thomazini D, Grzebielucka EC, Chinelatto AL, Chinelatto AS.. Estudos das propriedades de cerâmicas de Zr02-Y203 sinterizadas em forno convencional e de micro-ondas. The Management System for Facilities and Activities. 2006; 44:1-8.

18. Upadhyaya DD, Ghosh A, Dey GK, Prasad R, Suri AK. Microwave sintering of zirconia ceramics. J Mater Sci. 2001;36(19):4707-10.
19. Marinel S, Savary E. In situ measure mentof the shrinkage during microwave sintering. J Mater Process Technol. 2009 Jun;209(10):4784-8.

20. Kim H, Kim S, Lee J, Ha SR. Effects of surface treatments on the translucency, opalescence, and surface texture of dental monolithic zirconia ceramics. J Prosthet Dent. 2016 Jun;115(6):7739. doi: 10.1016/j.prosdent.2015.11.020.

21. Borrell A, Salvador MD, Peñaranda-Foix FL, Catala-Civera JM. Microwave sintering of zirconia materials: Mechanical al and microstructural properties. Inter J Appl Ceram Tech. 2013 Mar;10(2):313-20.

22. Monaco C, Prete F, Leonelli C, Esposito L, Tucci A. Microstructural study of microwave sintered zirconia for dental applications. Ceram Inter. 2015 Jan;41(1 Part B):1255-61.

23. Sujith AV, Amar Kumar N, Sharan N. Microwave sintering of zirconia and alumina. Inter J Recent Trends Eng Tech. 2009 Nov;1(3):320-3.

\section{Guilherme Ferreira de Siqueira \\ Anzaloni Saavedra \\ (Corresponding address)}

Department of Dental Materials and Prosthodontics, Institute of Science and Technology, Paulista State University (UNESP)

Avenida Engenheiro Francisco José Longo, 555, Jardim

São Dimas, São José dos Campos/SP, Brasil

(12) 39479032

Date submitted: 2017 0ct 08

E-mail: saavedra_guilherme@hotmail.com
Accept submission: 2017 Dec 13 